\title{
Studies on marine fungal-nematode associations and plant degradation ${ }^{1}$
}

\author{
Samuel P. Meyers and Bruce E. Hopper \\ Institute of Marine Science, University of Miami, Miami, Florida, USA, \\ and \\ Entomology Research Institute, Canada Department of Agriculture, Ottawa, Canada
}

\begin{abstract}
KURZFASSUNG: Studien über marine Pilz-Nematoden-Assoziationen und Pflanzendegradation. Untersuchungen am Seegras Thalassia testudinum KöNIG haben ergeben, daß sich hier Pilzinfektionen hinsichtlich der Komposition der beteiligten Gattungen und der Dynamik des Befalls von den am untergetauchten Holz festgestellten Infektionen unterscheiden. Bestimmte Pilze, insbesondere der Ascomycet Lindra thalassiae, leiten eine erhebliche Degradation des Blattgewebes ein und zeigen einen Entwicklungszyklus, welcher in Beziehung steht zum physiologischen Zustand der Wirtspflanze. Die Anwendung von Pilz-Zellulose-Matten als "Einfangsubstrat" war außerordentlich erfolgreich für das Erkennen ökologisch signifikanter Verschiebungen in den Nematodenkonzentrationen, insbesondere bei der omnivoren Art Metoncholaimus scissus. Die Aktivitätsmuster von $M$. scissus - ebenso wie die verschiedener foliicolöser Nematoden - deuten darauf hin, daß pilzinfizierte und zerfallende Pflanzenteile in entscheidendem Maße die biologische Aktivität dieser Tiere beeinflussen. Laboratoriumsanalysen degradierter Wollzellulosefilter lassen eine überraschend starke Vermehrung des Ascomyceten Lulworthia erkennen und gleichzeitig die Entwicklung einer beachtlichen Fauna assoziierter Nematodenarten, insbesondere von Viscosia macramphida und Leptolaimus plectoides. Im Verlaufe der weiteren Degradation der Wollzellulosematrix kommt es bei der Nematodenfauna zu entsprechenden Sukzessionen.
\end{abstract}

\section{INTRODUCTION}

Microbial degradation of plant substrates is a multiphasic phenomenon with diverse interrelationships and numerous degrees of complexities. For a complete picture of diagenesis of plant material by microorganisms, it is necessary to evaluate the contribution of one component of the microbial system to other closely associated organisms, or groups of organisms, with comparable nutritional requirements. Investigations reported in this paper deal specifically with the ascomycetous and deuteromycetous groups of the marine fungi (mycota) with primary emphasis on characteristics which might indicate the role of these heterotrophic microorganisms in trans-

1 Contribution No. 768 from the Institute of Marine Science, University of Miami, Miami, Florida, and from the Canada Department of Agriculture, Ottawa, Canada. This work was supported at the IMS by grant GM 12842 from the National Institutes of Health, USA. 
formation of complex substrates. Also presented are observations on correlative studies of marine nematodes, wherein fungal and nematode biotas have been found repeatedly in discrete habitats characterized by active degradation of cellulosic material.

Studies at the Institute of Marine Science (IMS) over the past 10 years, on the taxonomy, physiology and ecology of marine fungi, have contributed to our knowledge of the activities of the marine mycota. More recently, attention has been given to the role of these organisms in breakdown of cellulosic material and its contribution to estuarine productivity. These studies do not in any way preclude direct and indirect contribution of other organisms to these processes. We recognize that degradation of cellulosic material by fungi in the marine environment cannot be examined accurately without critical evaluation of other microorganisms as well as complex environmental factors. Nevertheless, by examination of specific organisms in the laboratory and under field conditions, and by analysis of associative phenomena, we should obtain a better understanding of the sequential events that underlie microbial transformation of complex polymers in the sea.

\section{METHODS AND MATERIALS}

The methodology followed in the mycological and nematological investigations reported have been described in detail in various communications listed in the Literature Cited section of this paper.

Stock cultures of marine fungi are maintained on seawater agar slants of $1 \%$ glucose and $0.25 \%$ Difco yeast extract in the Microbiology Section of the Institute of Marine Science.

Permanent mounts of the various marine nematode taxa discussed have been prepared and are on deposit in the Canadian National Collection of Nematodes, Ottawa, Canada.

\section{RESULTS AND DISCUSSION}

\section{Fungal infestation of turtle grass, Thalassia testudinum KöNIG}

The seagrasses, along with their composite epibiotic populations, comprise vast submerged meadows of productivity within estuaries and inshore environments of the sea. One plant, turtle grass (Thalassia testudinum KöNIG), is found in extensive beds throughout the Caribbean, along part of the Gulf coast of the United States, and along the lower east coast of Florida (MOORE 1963). This marine angiosperm provides one of the largest single ecological habitats of Western Atlantic tropical shallow waters.

Microbiological studies (Meyers et al. 1964, Meyers et al. 1965) of Thalassia at the IMS have shown the dynamics of fungal infestation and the nature of the mycota compared with that on submerged wood. Previous mycological investigations of marine 
vascular plants by others included only incidental isolations made during surveys or descriptions of new fungal taxa.

Findings from these investigations can be summarized as follows:

(a) The fungi on Thalassia leaves may be separated into three general groups based on relative abundance and frequency of isolation. Included in the dominant
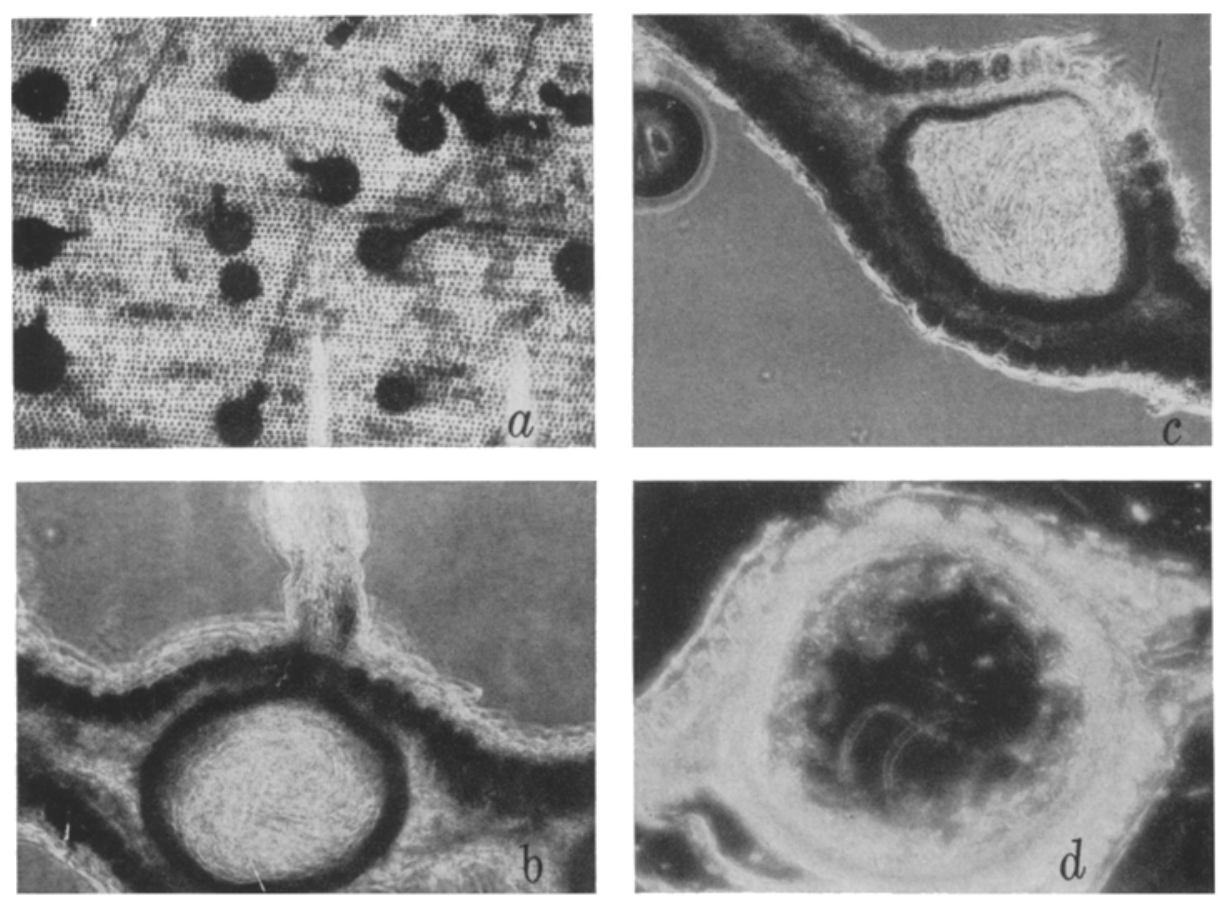

Fig. 1: Degradation of turtle grass leaf by Lindra thalassiae; (a) area of infested Thalassia leaf showing random development of $L$. thalassiae perithecia; (b) cross section of leaf with ostiolate perithecium; (c) cross section of leaf with papilliform perithecium; (d) cross section of papilliform perithecium showing wall structure and centrum cavity (phase contrast)

group are the Myxomycete Labyrintbula spp., the ascomycete Lindra thalassiae ORpurt et al., and the deuteromycetes Hormodendron sp., Cephalosporium sp., and Dendryphiella arenaria NicoT.

(b) Fluctuations in foliicolous fungal populations are noted during the year with an increase in Labryrintbula spp. and L. thalassiae in the late spring. Infestation of Thalassia leaves by $L$. thalassiae is shown in Figure 1 . The decided hypertrophy of leaf tissues in the immediate area of development of the fungal fruiting structures (perithecia) indicates the ability of the fungus to decompose this substrate.

(c) Intensity of development of Labyrintbula spp. and L. thalassiae in the leaves appears related to the physiological state of the host plant.

(d) Association of various of the fungi with particular gross morphological condition of the leaves is indicated. 
(e) Considerable variation is observed in infestation of separate areas of single leaves as well as among leaves of individual collections.

(f) Noteworthy differences are seen between the foliicolous and lignicolous (woodinhabiting) mycota of estuarine environments, both in generic composition and in dynamics of infestation. Species of Lulwortbia, common on wood, are absent from Thalassia whereas $L$. thalassiae has not been found on wood. A schematic diagram of seasonal infestation of Thalassia by foliicolous fungi is shown in Figure 2.

DEVELOPMENT OF FOLICOLOUS FUNG ON Thalossio festudinum KÖNIG IN BISCAYNE BAY, FLORIDA
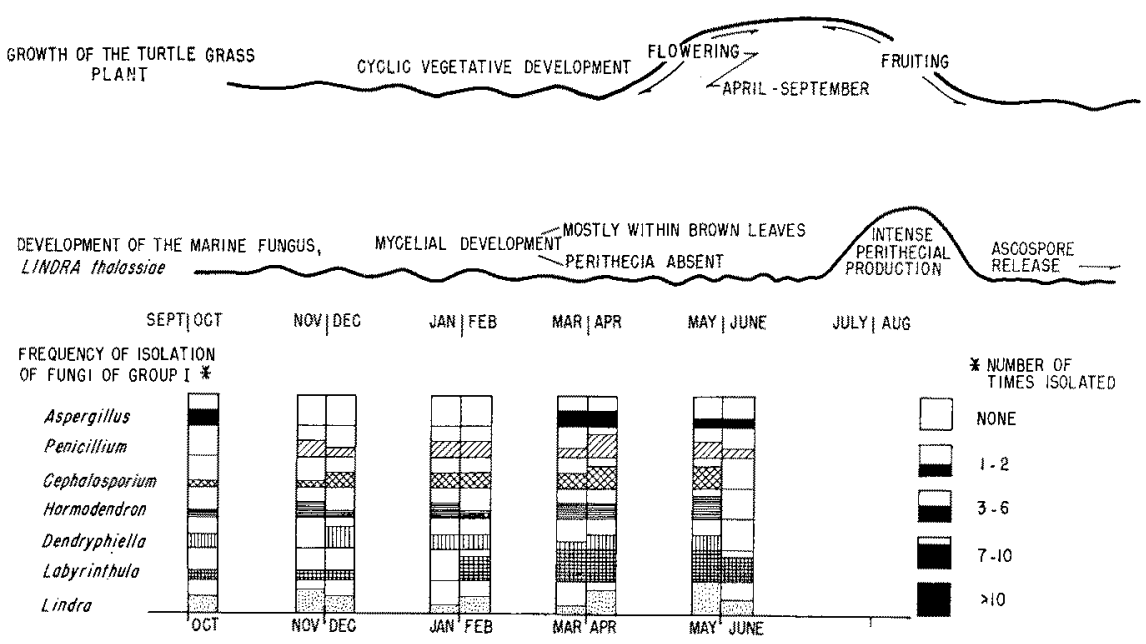

Fig. 2: Diagram of seasonal infestation of Thalassia by foliicolous fungi

At this stage it is not possible to estimate accurately the full contribution of marine fungi to decomposition of turtle grass. The need for studies of the role of other types of microorganisms, notably bacteria, in decomposition of the crude plant fiber is apparent. However, from work to date, it is clear that a diverse, and at times extremely abundant, population of fungi are associated with leaves of the plant at all stages of its development. Preliminary studies indicate that certain of these organisms have cellulolytic ability, and as noted for $L$. thalassiae, possess enzymatic capacity to degrade plant material in the natural environment.

\section{Cellulolytic activity of marine fungi}

Earlier work (MEYERS \& REYNOLDS 1960, 1963), has demonstrated the ability of lignicolous fungi to attack lignocellulose matrices with concurrent production of cellulolytic enzymes. The notable loss of strength of cordage when used as a growth substrate for the various fungi is a positive indication of the destructive action of these organisms on lignocellulose fibers. Similarly, enzymatic studies of pure cultures 
of different taxa of wood inhabiting Ascomycetes and Deuteromycetes (MEYERS \& REYNOLDS 1960), developing on Manila twine in culture vessels containing $0.1 \%$ yeast extract and sea water, have revealed extensive activity accompanied by significant loss in fiber tensile strength. Correlations between intensity of fungal reproduction and maximal fiber rupture have been noted for certain fungi.

Cordage exposed under field conditions rapidly (within two weeks) undergoes significant degradation with concurrent fungal attack. The latter occurs within five days following submergence with considerable variability in the intensity of attack along the length of cordage. The predominant fungi isolated have been species of Lulwortbia.

An increase in total reducing sugars (RS), together with specific production of glucose, from carboxymethylcellulose and Walseth cellulose, have been used as indices of the fungal hydrolysis of cellulose and cellulosic materials. Dissimilarities noted in cellulolytic activity and degradative properties of the fungi examined demonstrate the need to consider specificity of fungal activity for accurate interpretation of the role of fungi in marine biological processes.

\section{Folicolous nematodes and Thalassia degradation}

We have shown that foliicolous nematodes exhibit patterns of variability that differ widely among turtle grass communities in comparable ecosystems (HopPER \& MEYERs 1967). Senescence or decline of the epigrowth occasionally results in significant increases in number of various nematodes on the leaf surfaces. Perhaps declining habitats of this type permit greater sediment accumulation within the locality and allow for more effective nematode immigration. If this occurs, then in all likelihood the decline of the epigrowth does not affect the nematode population directly, but indirectly through increased accessibility of the habitat to the animal. Possibly, these changes in the bionomics of the foliicolous nematode population reflect differences in relative concentrations of organic deposition in the immediate locality. Studies of foliicolous fungi on Thalassia did not run concurrently with our examinations of the nematode populations present. It would be interesting to ascertain whether the latter organisms increase in numbers, or exhibit significant successional patterns, during periods of greater fungal infestation of the leaves. In particular, investigations must be made of the nematode population during reproduction of the Thalassia itself, when intensive development of the fungus, $L$. thalassiae, occurs, and the host plant is undergoing a series of biochemical changes concurrent with flowering and seed maturation. Unfortunately, the dynamic nature of such plant communities is frequently neglected by workers concerned only with tabulation of the associated flora and fauna.

\section{Attraction of nematodes to fungal substrates}

Nematological studies at the IMS (MeYERs, FEDER \& TSUE 1964) demonstrated ability of various fungi (especially Dendryphiella arenaria and Halosphaeria medio- 
setigera CRIBB \& CRIBB) to support development of a marine-isolated species of Aphelenchoides, a stylet-bearing nematode from the rhizosphere of Thalassia. As noted, $D$. arenaria is one of the dominant fungi in leaves of Thalassia. Species of Dendryphiella are widely distributed in intertidal regions, and one species, D. salina, has been found in such diverse habitats as plant rhizospheres, seaweeds, wood blocks, and recently in soil, algae and mosses from the Antarctic seashore. H. mediosetigera is abundant in estuarine waters where it rapidly attacks submerged wood and other

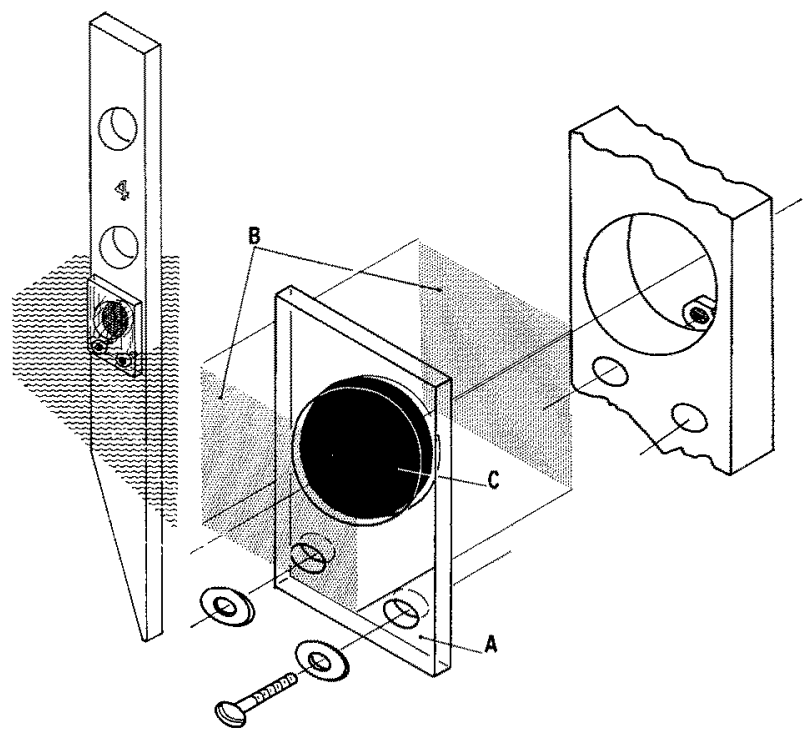

Fig. 3: Diagram of wooden stake and plastic carrier for nematode isolation. (a) plastic carrier;

(b) Saran screening to enclose chamber; (c) test substrate, fungal mat or cellulose control

cellulosic materials. A range of viable fungal mycelia supported growth and reproduction of Aphelenchoides sp., although considerable differences in rate of development of the nematode on various fungi were noted. Certain fungi were unable to support animal growth, whereas others, especially isolates of marine Deuteromycetes and Ascomycetes, were extremely effective as a food source. The response of the nematode to the particular fungus, termed the "utilization factor", was studied on a comparative basis at various stages of growth of the different fungi.

Methodology employing a fungal-cellulose mat to study sublittoral nematode populations in the field has been discussed earlier in our investigations of foliicolous and benthic nematodes, especially the bionomics of the omnivorous species, Metoncholaimus scissus (Hopper \& Meyers 1966, Meyers \& Hopper 1966). This procedure uses washed fungal mats grown in laboratory culture on cellulose discs $(4.2 \mathrm{~cm}$ diameter) for various periods. The two fungi used were $D$. arenaria and $H$, mediosetigera, both of which form a compact mat on the cellulose and remain intact during submergence. The fungal mats, or controls of cellulose alone, are placed within a plastic carrier attached at various positions to wood stakes, singly or in adjacent pairs (Fig. 3 ). 
Openings on both sides of the carrier are covered by $52 \times 52$ mesh Saran screen to permit ready internal passage of water and entry of the meiofauna present. The stakes are inserted vertically in the sediment and may be adjusted so that the fungal mat is either at the sediment or at various distances above it.

In our analyses of the bionomics of $M$. scissus we noted that the nematode fauna on the fungal substrate consisted almost entirely of this species with the majority of the population gravid females. Often concentrations approaching 3000 animals were tabulated. Sediment samples in the immediate vicinity of the test site showed a proportionate sex ratio of the species. Patterns of activity of $M$. scissus, both in numbers and ratios of sexes present, as well as variabilities in populations of other dominant benthic nematodes, suggest that discrete loci of organic material (such as fungal infested leaves and decaying plant tissue) significantly affect biological activity of segments of the meiobenthos. Striking differences have been noted in nematode colonization among closely situated sites, as well as in individual sites at the same and different collection periods. This microcolonization is affected more by discrete biochemical/biological factors and specific characteristics of the nematode species than by differences in gross physical features of the sediment. The response of $M$. scissus to the test substrates did not appear to be one of feeding alone, but more likely was an attraction to substance (s) emitted by the fungal cellulose complex during degradation. We postulated that the attractant (s) may originate either directly from the latter, possibly as autolytic products, or from the associated microbiota that rapidly colonize the substrata following submergence.

Thus, the fungal mat method is effective for partial evaluation of marine nematode populations and especially for discernment of ecologically significant shifts in animal concentrations and microsite dissimilarities. In addition, laboratory incubation of the exposed fungal mats, along with use of fungal mycelia for cultivation of nematodes, has permitted accumulation of various pertinent information on the life cycle of nematodes in subtropical waters (HOPPER \& MEYERS 1966b).

\section{Association of fungi and nematodes on cotton cellulose}

Recent isolations have verified our earlier observations in Biscayne Bay on the occurrence of certain fungi with marine nematodes on cellulosic substrates at diverse stages of degradation. Examination of a cotton cellulose filter in the flowing seawater system (gravity-fed from a roof settling tank, piped from an inlet at the IMS pier) of one of the IMS laboratories revealed an interesting pattern of fungal and nematode colonization. The filter tube (C 50 AIOU, Filterite Corp., Timonium, Maryland, USA) was a $50 \mu$ cotton filter element, $2 \frac{1}{2}$ inches outside diameter by 10 inches long, on a polypropylene center core. The cotton fiber when wound on the filter tube had been kier-boiled and bleached and dry textile processed. While it has not been possible to establish precisely the period of exposure of the filter, a period of approximately 3 months is estimated.

Initial inspection showed striking decomposition of the filter with only a small portion of the original matrix remaining on the plastic core (Fig. 4). The fiber was 

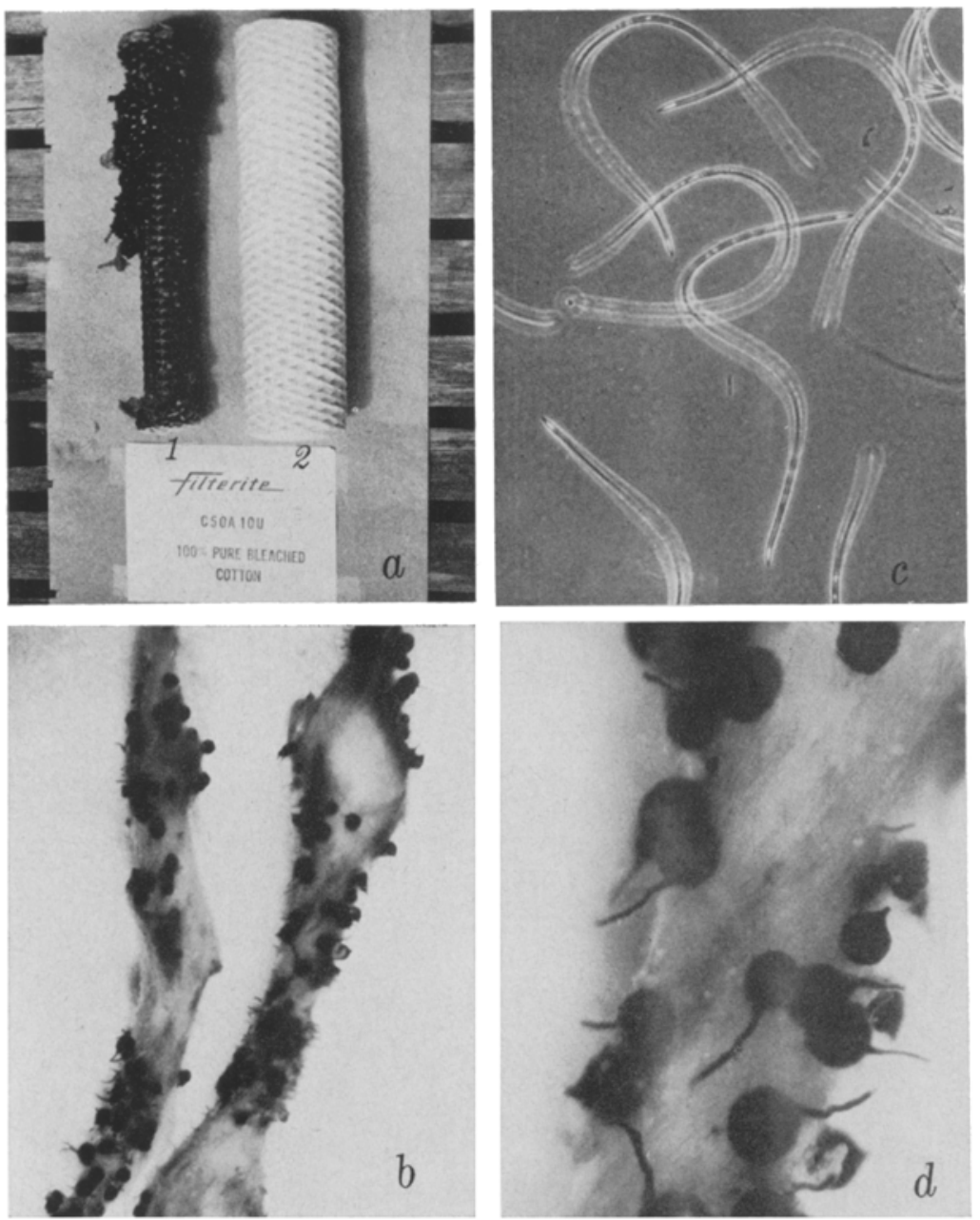

Fig. 4: Fungal infestation of cotton cellulose filters: (a) cotton filter used in seawater system, (2) un-used filter (control), (1) after fungal infestation; (b) strands of fiber showing development of dark fruiting bodies (perithecia) of Lulwortbia; (c) filamentous ascospores of Lulworthia, about 300 microns long; (d) individual cotton strand showing long neck present on perithecia

discolored with negligible residual tensile strength. Along the entire length of the cotton strands were tremendous concentrations of mature fruiting structures (perithecia) of a marine Ascomycete of the ubiquitous genus Lulworthia. Although sections of the decomposed fiber were plated repeatedly on appropriate nutrient culture media, the only fungus isolated, other than Lulworthia sp., was a species of Fusarium.

The widespread occurrence of representatives of Lulworthia is well documented in marine mycological literature (Johnson \& SPARRow 1961). Species of this scolecosporous Ascomycete comprise a significant part of the mycota found in early infes- 
tation of submerged wood and other cellulosic substrates. In Biscayne Bay, Florida, reproduction by Lulworthia often occurs on test panels within 10 days following exposure. In northern and arctic locales, wood panels submerged in waters of temperatures of $<10 \mathrm{C}$ also have been actively attacked by species of Lulwortbia, although submergence periods of 100 to 200 days frequently were required for fungal reproductive structures to appear (Meyers \& Reynolds 1960). The isolates of Lulworthia from the cotton filter currently are being examined at the IMS, especially for characterization of cellulolytic activity. In earlier degradation studies of cellulolytic activity of isolates of Lulworthia (MEyERs \& REYNOLDs 1963), L. floridana caused significant reduction in strength of cordage fiber, while eight other Lulworthias isolated from Manila cordage exposed at the IMS pier were inactive. In general, Lulwortbia spp. are less active than other marine Ascomycetes, i. e., Halosphaeria mediosetigera.

Inspection of the cotton filter fiber revealed a noticeable nematode population, the majority of which were Leptolaimus plectoides CHITw ood (1951). Of 55 specimens selected at random, 45 were $L$. plectoides, while the remainder consisted of specimens of Araeolaimus, Prochromadorella, and Acantbonchus. The Leptolaimus population was devoid of males with only females and juveniles present. Further observations on L. plectoides suggest that this species has a very short life cycle, probably within two weeks. Scarcity of males indicates that it can reproduce parthenogenetically. Little information is available on the bionomics of Leptolaimus, and many of the original species descriptions were based on single specimens. In our unpublished nematological studies of sediments in Biscayne Bay, specimens of a Leptolaimus were rarely found. It appears that representatives of this genus are quite selective in their choice of habitats. Examination of isolation records of Leptolaimus species shows a possible

Table 1

Occurrence and percent frequency of nematodes on degraded cotton fibres

\begin{tabular}{|c|c|c|c|c|c|c|c|c|c|c|}
\hline \multirow{3}{*}{$\begin{array}{c}\text { Collection } \\
\text { No. }\end{array}$} & \multirow{3}{*}{$\begin{array}{c}\text { Total number } \\
\text { of } \\
\text { nematodes }\end{array}$} & \multicolumn{9}{|c|}{ Taxa of nematodes present } \\
\hline & & 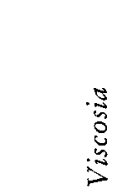 & 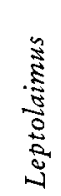 & 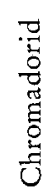 & 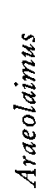 & 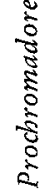 & 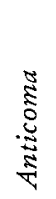 & 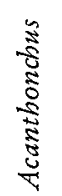 & 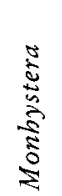 & 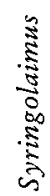 \\
\hline & & \multicolumn{9}{|c|}{ Percent frequency of occurrence in sample } \\
\hline & & $\%$ & $\%$ & $\%$ & $\%$ & $\%$ & $\%$ & $\%$ & $0 \%$ & $\%$ \\
\hline 1 & 53 & 0 & 85 & 0 & 9 & 2 & 0 & 4 & 0 & 0 \\
\hline 2 & 39 & 2 & 90 & 0 & 5 & 0 & 2 & 0 & 0 & 0 \\
\hline 3 & 64 & 48 & 26 & 3 & 3 & 11 & 0 & 8 & 0 & 0 \\
\hline 4 & 39 & 26 & 38 & 20 & 3 & 3 & 5 & 5 & 0 & 0 \\
\hline 5 & 29 & 79 & 7 & 10 & 0 & 3 & 0 & 0 & 0 & 0 \\
\hline 6 & 39 & 31 & 18 & 20 & 2 & 2 & 21 & 0 & 2 & 2 \\
\hline 7 & 34 & 29 & 32 & 32 & 0 & 0 & 0 & 6 & 0 & 0 \\
\hline 8 & 20 & 5 & 45 & 40 & 0 & 0 & 0 & 0 & 5 & 5 \\
\hline 9 & 80 & 49 & 21 & 9 & 0 & 7 & 0 & 1 & 11 & 1 \\
\hline 10 & 129 & 43 & 32 & 19 & 0 & 0 & 0 & 3 & 3 & 0 \\
\hline
\end{tabular}


association with detrital material or substrates in which degradation of organic matter would be expected to occur. Subsequent examination of the filter, maintained in a small aquarium of running sea water, revealed other nematode taxa, especially Viscosia macramphida. A pattern of succession of nematode species has been observed (Table 1). In collections of degraded fiber over a six week period, the dominant animals have been, in descending order of abundance, V. macramphida, L. plectoides, and an unidentified chromadorid. Examination of intact fiber and detrital material within the container revealed similar specimens, especially those of Viscosia.

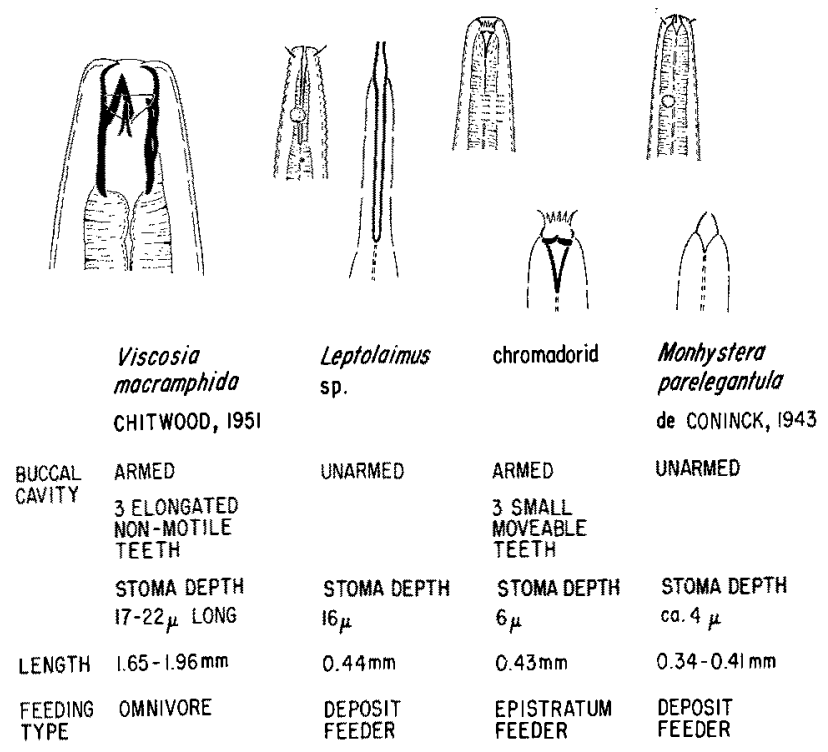

Fig. 5: Diagram and salient characteristics of the four major nematode taxa present within the cotton cellulose filter. Drawings are all on a similar comparative size basis. Enlargement of the buccal cavity area is given for Leptolaimus sp. (plectoides), chromadorid, and Monbystera parelegantula

The filter habitat seems to support four distinct nematode populations: viz. Viscosia, Leptolaimus, the chromadorid and Monbystera spp. (M. parva and M. parelegantula). These taxa represent three, possibly four, different levels of feeding based on the stomatal structure of each genus: Viscosia - an omnivore; chromadorid - an epistratum feeder; Leptolaimus and Monbystera - either selective or non-selective deposit feeders. The distinctive cylindroid stoma and small basal bulb at the end of the esophagus of Leptolaimus may permit this animal to utilize a slightly different food material than species of Monhystera. We recognize that designation of feeding type, as noted above, is arbitrary, with various exceptions, possible, particularly in the unique fiber habitat. Dominance of certain species may be a reflection of the physico-chemical nature of the fiber matrix rather than a response to a particular usable food source. Hopefully, our studies in progress on individual nematode species will eventually elucidate specific nutrient requirements and provide essential bionomic data required for evalution of these animals. 
Direct correlations between fungal development and concentration of nematodes are not obvious or possible at this time. In various aquarial tests, wood panels with extensive reproductive development of Lulworthia sp. show only sparse populations of nematodes. Similar observations have been noted in the field except for several collections of fungal infested wood supporting considerable numbers of almost pure cultures of Oncholaimus dujardinii. An array of different stages of development of the species were present on the wood. The possibility of specificity of nematode colonization in relation to certain fungi or to fungal metabolic products cannot be excluded. The latter may stimulate development of associated microorganisms, i. e., bacteria, diatoms, ciliates, protozoa, that more readily serve directly as food for the nematodes. Information on individual and combined activities of these various organisms is needed. These data, together with further characterization of the biochemical processes and physiological ecology of marine fungi, should assist us in better understanding plant degradation in the sea.

\section{SUMMARY}

1. Studies of the broad-leafed turtle grass, Thalassia testudinum KöNIG, have revealed a diverse range of fungal infestation different in generic composition and dynamics of attack from that found on submerged wood. Certain of the fungi, notably the Ascomycete Lindra thalassiae, initiate considerable degradation of leaf tissue and show a developmental cycle in nature related to the physiological state of the host plant.

2. Use of fungal-cellulose mats as a "trapping" substrate has been extremely effective for discernment of ecologically significant shifts in nematode concentrations, especially those of the omnivorous species, Metoncholaimus scissus.

3. Patterns of activity of $M$. scissus, as well as those of various foliicolous nematodes, suggest that loci of organic material, such as fungal infested leaves and decaying plant tissue, significantly affect biological activity of these animals.

4. Laboratory analysis of degraded cotton cellulose filters show a striking incidence of fungal reproduction of the ascomycetous fungus Lulwortbia, along with development of a considerable associated nematode fauna, especially species of Viscosia (V. macramphida) and Leptolaimus (L. plectoides). Successional patterns in nematode development are noted with continued degradation of the cotton cellulose matrix.

\section{ACKNOWLEDGMENTS}

Dr. C. MARTIN, IMS, called our attention to the cotton cellulose filter and kindly took the photographs illustrated in Figure 4 of this paper. Technical assistance has been ably provided by Mr. W. Aring and Miss R. Cefalu of IMS.

\section{LITERATURE CITED}

Hopper, B. E. \& Meyers, S. P., 1966a. Observations on the bionomics of the marine nematode, Metoncholaimus sp. Nature, Lond. 209, 899-900. 
- $-1966 \mathrm{~b}$. Aspects of the life cycle of marine nematodes. Helgoländer wiss. Meeresunters. 13, 444-449.

- - 1967. Follicolous marine nematodes on turtle grass, Thalassia testudinum KöNIG, in Biscayne Bay, Florida. Bull. mar. Sci. Gulf Caribb. 17, 471-517.

Johnson, T. W., Jr. \& Sparrow, F. K., Jr., 1961. Fungi in oceans and estuaries. Cramer, Weinheim, $668 \mathrm{pp}$.

Meyers, S. P., Feder, W. A. \& Tsue, K. M., 1964. Studies of relationships among nematodes and filamentous fungi in the marine environment. Devs ind. Microbiol. 5, 354-364.

- \& Hopper, B. E., 1966. Attraction of the marine nematode, Metoncholaimus sp., to fungal substrates. Bull. mar. Sci. Gulf Caribb. 16, 143-150.

- Orpurt, P. A., Boral, L. L. \& Simms, J., 1964. Thalassiomycetes. 5. A new species of Lindra from turtle grass, Thalassia testudinum KöNIG. Bull. mar. Sci. Gulf Caribb. 14, 405-417.

- - Simms, J. \& Borat, L. L., 1965. Thalassiomycetes. 7. Observations on fungal infestation of turtle grass, Thalassia testudinum KönIG. Bull. mar. Sci. Gulf Caribb. 15, 548-564.

- \& ReYnolds, E. S., 1960a. Occurrence of lignicolous fungi in northern Atlantic and Pacific marine localities. Can. J. Bot. 38, 217-226.

- $1960 \mathrm{~b}$. Cellulolytic activity of lignicolous marine Ascomycetes and Deuteromycetes. Devs ind. Microbiol. 1, 157-168.

- - 1963. Degradation of lignocellulose material by marine fungi. In: Symposium on marine microbiology. Ed. by C. H. Oppenheimer. C. C. Thomas, Springfield, Ill., 315-328.

Moore, D. R., 1963. Distribution of the sea grass, Thalassia, in the U.S. Bull. mar. Sci. Gulf Caribb. 13, 329-342.

Wieser, W. \& Hopper, B. E., 1967. Marine nematodes of the east coast of North America. 1. Florida. Bull. Mus. comp. Zool. Harv. 135, 239-344.

\section{Discussion following the paper by MEYERS \& HOPPER}

v. THun: Sie erwähnen besonders Metancholaimus scissus, den Sie für omnivor halten. Nun, ich glaube, daß diese Art, ebenso wie andere Vertreter der Oncholaimiden, die ich selbst beobachtet habe, carnivor ist. Das Auffinden yon Pilzteilen im Darmkanal wäre durchaus dadurch zu erklären, daß sekundär, durch Aussage anderer phytophager Mitbewohner, diese mit dem Körperinhalt des Beutetiers mitaufgenommen werden.

Meyers: We are of course familiar with the literature which suggests that the Oncholaimidae are a predatory group. However, recent observations by various investigators indicate that these animals have a wider latitude of food selection than previously thought, and in fact, may function as omnivores. Certain of these species have been considered to derive nutrition by passage of sedimentary material through their alimentary tract. Unfortunately, too little is known about the basic biology of marine nematodes to draw broad conclusions on their food selection and other characteristics at this time. Overgaard Nielsen and others have stressed that a well-packed lumen is not direct evidence that substances in the culture medium necessarily constitute the diet of the animal in the field. Considerable work must be done in this area before we can accurately access the role of nematodes in biological processes in the environment.

v. Thun: Haben Sie feststellen können, daß ganze Pilze oder Teile davon durch Nematoden aufgenommen wurden?

Meyers: We have not observed these animals feeding directly on fungi and the "attraction" of the species to the fungal-cellulose mats is not one of feeding or solely a substrate response, but is more likely a reaction to substance(s) emitted from the fungal-cellulose complex as it undergoes degradation. Until we have a better picture of the microbiota that colonize submerged substrata, and understand the dynamics and sequence of their processes, it would be unwise to totally exclude any sediment component from the biology of the nematode population. 